\title{
ANALISIS DISKRIMINAN OPERATOR SELULER TELKOMSEL DAN OPERATOR SELULER LAINNYA (INDOSAT OOREDOO, XL AXIATA, 3) TERHADAP KEPUTUSAN BRAND SWITCHING DI STIE DEWANTARA
}

\author{
${ }^{1)}$ Benny Osta Nababan, ${ }^{2)}$ Irhaz Ambiatul Awwalin \\ ${ }^{1)}$ Dosen Tetap Program Studi Manajemen, STIE Dewantara \\ J1. Raya Pemda Bojong Depok Baru III Karadenan Cibinong Bogor, Jawa Barat 16913, Indonesia \\ Email: benny.osta@dewantara.ac.id \\ ${ }^{2)}$ Alumni Program Studi Manajemen, STIE Dewantara \\ J1. Raya Pemda Bojong Depok Baru III Karadenan Cibinong Bogor, Jawa Barat 16913, Indonesia \\ Email:irhazambi2@gmail.com
}

\begin{abstract}
The purpose of this study was to compare the independent variables of Telkomsel cellular operators with other operators and determine the discriminant model of the brand switching of cellular operators Telkomsel. The approach used in this study is a comparative quantitative method. Independent variable consisting of product quality $(X 1)$, price $(X 2)$, promotion $(X 3)$ and brand image (X4), the dependent variable is Brand Switching (Y). The population of this study was 1028 STIE Dewantara (Odd Year 2015-2018) students. The number of samples taken was 100 samples with Slovin formula with alpha 5\%. Data analysis using discriminant analysis. The results showed that the variables used in this study were overall valid and reliable so that the data obtained could be used in discriminant analysis of cellular operators of Telkomsel and other cellular operators. The value of consumer satisfaction of cellular operators is, on average, more satisfied to Telkomsel cellular operators, which is shown by the average value of satisfaction of 397.07 points while other cellular operators amount to 357.87 points. There are 3 differences in consumer perceptions of cellular operators towards Telkomsel. The difference in perception is in the variables of product quality, promotion and brand image. This means that users of cellular operators will compare these 3 variables before making a move to the Telkomsel brand.
\end{abstract}

Keywords: Product Quality, Price, Promotion, Brand Switching, Telkomsel, Indosat, XL Axiata, 3.

\section{ABSTRAK}

Tujuan penelitian ini adalah untuk membandingkan variabel bebas operator seluler Telkomsel dengan operator lainnya dan menentukan model diskriminan brand switching operator seluler Telkomsel. Pendekatan yang digunakan pada penelitian ini adalah metode kuantitatif komparatif. Variabel independen yang terdiri dari Kualitas produk $\left(\mathrm{X}_{1}\right)$, Harga $\left(\mathrm{X}_{2}\right)$, Promosi $\left(\mathrm{X}_{3}\right)$ dan Brand Image $\left(\mathrm{X}_{4}\right)$, variabel dependennya adalah Brand Switching (Y). Populasi penelitian ini adalah Mahasiswa STIE Dewantara (Tahun Ganjil 2015-2018) sebanyak 1028. Jumlah sampel yang diambil sebanyak 100 sampel dengan rumus Slovin dengan alpha 5\%. Analisa data menggunakan anlisis diskriminan. Hasil penelitian menunjukkan variabel yang digunakan dalam penelitian ini secara keseluruhan valid dan reliabel sehingga data yang diperoleh dapat digunakan dalam Analisis diskriminan operator seluler Telkomsel dan operator seluler lainnya. Nilai kepuasan konsumen operator seluler secara rata-rata lebih puas kepada operator seluler Telkomsel, yang ditunjukan oleh nilai rata-rata kepuasan sebesar 397,07 point sedangkan operator seluler lainnya sebesar 357,87 point. Ada 3 perbedaan persepsi konsumen operator seluler terhadap Telkomsel. Perbedaan persepsi tersebut ada pada variabel kualitas produk, promosi dan brand image. Artinya pengguna operator seluler akan membandingkan 3 variabel tersebut sebelum melakukan perpindahan ke merek Telkomsel.

Kata kunci: Kualitas Produk, Harga, Promosi, Brand Switching, Telkomsel, Indosat, XL Axiata, 3. 


\section{PENDAHULUAN}

\subsection{Latar belakang}

Komunikasi merupakan kebutuhan yang tidak dapat dipisahkan di dalam kehidupan bermasyarakat, dengan adanya perkembangan ilmu pengetahuan dan teknologi menjadikan komunikasi jarak jauh pun bisa dilakukan terasa dekat oleh berbagai macam cara, salah satunya menggunakan telepon selular canggih (smartphone). Melihat keuntungan yang sangat menjanjikan karena kebutuhan masyarakat dalam berkomunikasi di era modern sekarang, dan dengan hadirnya smartphone murah yang mampu dijangkau berbagai lapisan masyarakat dan kecendrungan memiliki ponsel lebih dari satu dengan fitur dual SIM card. menjadikan banyak industri dan perusahan swasta bermunculan termasuk salah satunya di industri telekomunikasi yaitu Perusahaan operator seluler.

Perkembangan Industri telekomunikasi di Indonesia berawal dari disahkannya Undang-Undang Republik Indonesia No 36 Tahun 1999 tentang Telekomunikasi yang menyebutkan bahwa "Badan Usaha Milik Negara (BUMN), Badan Usaha Milik Daerah (BUMD) dan Badan Usaha Swasta dan Koperasi dapat melakukan penyelenggaraan jasa telekomunikasi”. Mengingat indonesia termasuk dalam anggota G20 yaitu negara dengan perekonomian besar dengan jumlah penduduk di tahun 2017 mencapai 261 juta jiwa, dengan jumlah populasi tersebut menjadi sebuah peluang bagi pengusaha untuk berbisnis di negeri ini dan melakukan persaingan melihat keuntungan yang sangat menjanjikan.

Hal tersebut dapat kita lihat dari data pelanggan 4 operator selular di bawah ini:
Jumlah Pelanggan Operator Seluler...

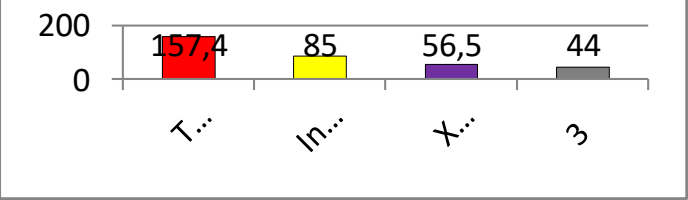

Gambar 1. Jumlah pelanggan operator seluler 2016

Sumber : Katadata Indonesia, 2017.

Berdasarkan data pada Gambar 1.1 menjelaskan bahwa jumlah total pelanggan operator seluler terbanyak di Indonesia pada tahun 2016 mencapai 157,4 juta pelanggan dimiliki oleh operator seluler Telkomsel. Telkomsel mendominasi pangsa pasar dalam negeri jauh di atas para pesaingnya dengan indosat 85 juta pelanggan Tri 56.5 juta pelanggan dan XL 44 Juta pelanggan.

\subsection{Rumusan masalah}

Berdasarkan identifikasi masalah, dapat dirumuskan beberapa masalah yang akan diteliti sebagai berikut:

1. Bagaimana membandingkan variabel bebas operator seluler Telkomsel dengan operator lainnya?

2. Bagaimana menentukan variabel bebas dari perbedaan antar grup (operator seluler Telkomsel dan operator seluler Lainnya)?

3. Bagaimana mengetahui perilaku pengguna operator seluler (operator seluler Telkomsel dan operator seluler Lainnya)?

4. Bagaimana menentukan seberapa besar variabel terikat (operator seluler) dapat dijelaskan oleh variabel bebasnya oleh model diskriminannya?

5. Bagaimana menentukan apakah terdapat perbedaan antara operator seluler Telkomsel dan operator seluler Lainnya? 
6. Bagaimana menentukan variabel bebas yang masuk grup operator seluler Telkomsel dan operator seluler Lainnya sehingga bersikap positif terhadap atribut variabel bebas?

7. Bagaimana menentukan model diskriminan brand switching operator seluler Telkomsel?

8. Bagaimana menentukan apakah model diskriminan tersebut mampu melakukan klasifikasi/prediksi responden dengan tepat untuk analisis diskriminan?

\subsection{Tujuan penelitian}

Adapun tujuan penelitian yang penulis lakukan:

1. Untuk membandingkan variabel bebas operator seluler Telkomsel dengan operator lainnya.

2. Untuk menentukan variabel bebas dari perbedaan antar grup (operator seluler Telkomsel dan operator seluler lainnya).

3. Untuk mengetahui perilaku pengguna operator seluler (operator seluler Telkomsel dan operator seluler lainnya).

4. Untuk menentukan seberapa besar variabel terikat (operator seluler) dapat dijelaskan oleh variabel bebasnya oleh model diskriminannya.

5. Untuk menentukan apakah terdapat perbedaan antara operator seluler Telkomsel dan operator seluler lainnya.

6. Untuk menentukan variabel bebas yang masuk grup operator seluler Telkomsel dan operator seluler Lainnya sehingga bersikap positif terhadap atribut variabel bebas.

7. Untuk menentukan model diskriminan brand switching operator seluler Telkomsel.

8. Untuk menentukan apakah model diskriminan tersebut mampu melakukan klasifikasi/prediksi responden dengan tepat untuk analisis diskriminan.

\section{TINJAUAN PUSTAKA}

\subsection{Landasan Teori}

Pada tinjauan pustaka, akan dikemukakan teori-teori, penelitianpenelitian dan publikasi umum yang ada hubungannya dengan penelitian untuk dijadikan landasan teori dalam pelaksanaan penelitian ini.

\subsubsection{Bauran Pemasaran (Marketing Mix)}

Kotler \& Keller (2016:48) menjelaskan dan mengklasifikasikan bauran pemasaran sendiri adalah seperangkat alat pemasaran yang dikenal dengan istilah 4P, yaitu product (produk), price (harga), place (tempat) dan promotion (promosi), sedangkan dalam manajemen pemasaran modern dan juga jasa memiliki beberapa alat pemasaran tambahan seperti people (orang), process (proses), programs (program) dan physical evidence (fasilitas fisik) Berikut penjelasan mengenai 8P, sebagai berikut :

1. Produk (Product)

Produk adalah mengelola unsur produk termasuk perencanaan dan pengembangan produk atau jasa yang tepat untuk dipasarkan

2. Harga (Price)

Harga adalah suatu sistem menejemen perusahaan yang akan menentukkan harga dasar yang tepat bagi produk atau jasa

3. Distribusi (Place) Distribusi yakni memilih dan mengelola saluran perdagangan yang dipakai untuk menyalurkan produk atau jasa.

4. Promosi (Promotion)

Promosi adalah suatu unsur yang digunakan untuk memberitahukan dan membujuk pasar tentang produk atau jasa yang baru pada perusahaan 
melalui iklan, penjualan pribadi, promosi penjualan, maupun publikasi.

5. Orang (People)

Orang adalah semua pelaku yang memainkan peranan penting dalam penyajian jasa sehingga dapat mempengaruhi persepsi pembeli. Elemen dari orang adalah pegawai perusahaan, konsumen, dan konsumen lain.

6. Proses (Process)

Proses adalah semua prosedur awal, mekanisme, dan aliran aktivitas yang digunakan untuk menyampaikan jasa. Elemen proses ini memiliki arti sesuatu untuk menyampaikan jasa.

7. Program (Programs)

Program merupakan salah satu tambahan dari bauran pemasaran yang sudah ada.

8. Fasilitas Fisik (Physical Evidence)

Fasilitas fisik adalah merupakan hal yang nyata yang turut mempengaruhi keputusan konsumen untuk membeli atau menggunakan jasa yang ditawarkan.

Berdasarkan penjelasan tersebut mengenai bauran pemasaran, maka dapat disimpulkan bahwa bauran pemasaran merupakan seperangkat alat pemasaran untuk mempengaruhi pembeli atau konsumen.

\subsection{Definisi Operasional}

Tabel 1. Definisi operasional penelitian dari Kualitas Produk, Harga, Promosi, dan Citra Merek (Brand Image).

\begin{tabular}{|c|c|c|c|}
\hline No & Dimensi & Indikator & Nilai \\
\hline 1 & $\begin{array}{l}\text { Kualitas produk } \\
\text { adalah karakteristik } \\
\text { suatu produk atau } \\
\text { jasa yang } \\
\text { menunjang } \\
\text { kemampuannya } \\
\text { untuk memuaskan } \\
\text { kebutuhan } \\
\text { pelanggan. Kotler } \\
\text { dan Amstrong } \\
(\mathbf{2 0 1 2 : 2 3 0 )}\end{array}$ & $\begin{array}{l}1.1 . \\
\text { Keragaman } \\
\text { produk } \\
\text { (Product } \\
\text { Variety) } \\
\text { 1.2. Fitur } \\
\text { (Feature) } \\
\text { 1.3. Kualitas } \\
\text { kinerja } \\
\text { (Performance } \\
\text { Quality) }\end{array}$ & $\begin{array}{l}\text { Skala } \\
\text { Likert }\end{array}$ \\
\hline
\end{tabular}

\begin{tabular}{|c|c|c|c|}
\hline & & $\begin{array}{l}\text { 1.4. Pelayanan } \\
\text { (Services) } \\
\text { 1.5. Keandalan } \\
\text { (Reability) } \\
\text { 1.6. Imbalan } \\
\text { (Returns) } \\
\text { Kotler dan } \\
\text { Keller } \\
\text { (2016:47) }\end{array}$ & \\
\hline 2 & $\begin{array}{l}\text { Harga adalah } \\
\text { sejumlah uang yang } \\
\text { dibebankan atas } \\
\text { suatu barang atau } \\
\text { jasa atau jumlah dari } \\
\text { nilai uang yang } \\
\text { ditukar konsumen } \\
\text { atas manfaat- } \\
\text { manfaat karena } \\
\text { memiliki atau } \\
\text { menggunakan } \\
\text { produk atau jasa } \\
\text { tersebut. Kotler dan } \\
\text { Amstrong (2012 : } \\
\text { 151) }\end{array}$ & $\begin{array}{l}.1 . \\
\text { Keterjangkauan } \\
\text { harga } \\
\text { 2.2. Kesesuaian } \\
\text { harga dengan } \\
\text { kualitas produk } \\
\text { 2.3. Daya saing } \\
\text { harga } \\
\text { Kotler } \\
(\mathbf{2 0 1 1 : 3 4 5 )}\end{array}$ & $\begin{array}{l}\text { Skala } \\
\text { Likert }\end{array}$ \\
\hline 3 & $\begin{array}{l}\text { Promosi adalah } \\
\text { aktivitas yang } \\
\text { mengkomunikasikan } \\
\text { keunggulan produk } \\
\text { dan membujuk } \\
\text { pelanggan untuk } \\
\text { membeli produk itu. } \\
\text { Kotler dan } \\
\text { Amstrong } \\
\text { (2014:77) }\end{array}$ & $\begin{array}{l}\text { 3.1. } \\
\text { Advertising } \\
\text { 3.2. Even and } \\
\text { experience } \\
\text { 3.3. Online and } \\
\text { social media } \\
\text { marketing } \\
\text { 3.4. Word of } \\
\text { mouth } \\
\text { 3.5. Direct and } \\
\text { database } \\
\text { marketing } \\
\text { 3.6. Personal } \\
\text { selling } \\
\text { Kotler dan } \\
\text { Keller } \\
\text { (2012:478) }\end{array}$ & $\begin{array}{l}\text { Skala } \\
\text { Likert }\end{array}$ \\
\hline 4 & $\begin{array}{l}\text { Citra merek adalah } \\
\text { sekumpulan } \\
\text { keyakinan terhadap } \\
\text { suatu merek disebut } \\
\text { citra merek. Kotler } \\
\text { dan Amstrong } \\
\text { (2014:233) }\end{array}$ & $\begin{array}{l}\text { 4.1. Citra } \\
\text { Produk } \\
\text { 4.2. Citra } \\
\text { Korporat } \\
\text { 4.3. Citra } \\
\text { Pemakai } \\
\text { Sulistyari } \\
\text { (2012:4) }\end{array}$ & $\begin{array}{l}\text { Skala } \\
\text { Likert }\end{array}$ \\
\hline
\end{tabular}




\subsection{Kerangka Pemikiran}

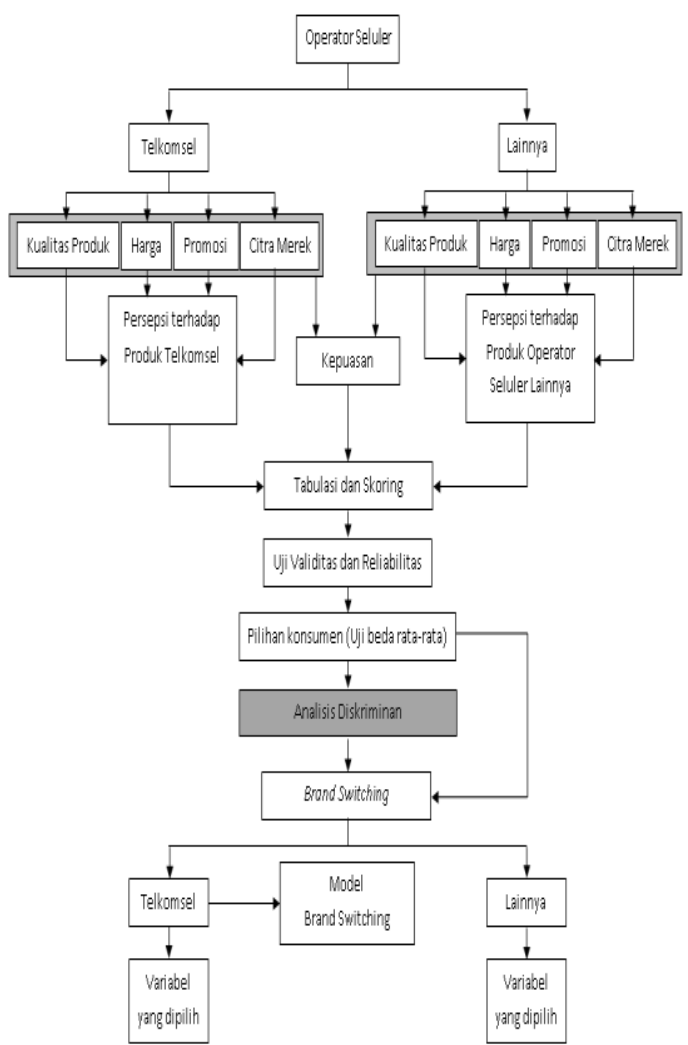

Gambar 2. Kerangka Penelitian

\section{METODE PENELITIAN}

\subsection{Jenis Penelitian}

Penelitian ini merupakan penelitian kuantitatif, yaitu penelitian tentang data yang dikumpulkan dan dinyatakan dalam bentuk angka-angka.

\subsection{Variabel Penelitian}

Dalam penelitian ini menggunakan variabel independen yang terdiri dari Kualitas produk $\left(\mathrm{X}_{1}\right)$, Harga $\left(\mathrm{X}_{2}\right)$, Promosi $\left(\mathrm{X}_{3}\right)$ dan Brand Image $\left(\mathrm{X}_{4}\right)$ dan variabel dependen yang digunakan dalam penelitian ini adalah Brand Switching (Y).

\subsection{Lokasi dan Waktu Penelitian}

Untuk memperoleh data yang obyektif sebagaimana yang diperlukan untuk menyusun metodologi penelitian ini, penulis melakukan penelitian di STIE Dewantara yang beralamat di Acropolis Blok LC No. 19 Jalan Raya Pemda Bojong
Depok Baru III, Karadenan, Cibinong Bogor. Dan Waktu penelitian dilakukan tahun 2018.

\subsection{Objek Penelitian}

Objek penelitian dalam penelitian ini adalah Mahasiswa STIE Dewantara yang pernah menggunakan operator seluler Indosat Ooredoo, XL Axiata, dan 3 kemudian Brand Switching ke operator seluler Telkomsel

\subsection{Populasi dan Sample}

Populasi penelitian ini adalah Mahasiswa STIE Dewantara (Tahun Ganjil 2015-2018) yang berjumlah 1028. Adapun pengambilan sampel dalam penelitian ini menggunakan purposive sampling. Teknik sampel yang dipakai adalah Rumus Slovin dengan toleransi kesalahan $10 \%$. Perhitungannya sebagai berikut:

$$
\begin{aligned}
& =\frac{1028}{1+1028\left(0.1^{2}\right)} \\
& =\frac{1028}{11.28} \\
n & =91,13
\end{aligned}
$$

Jumlah sampel yang diambil sebanyak 100 sampel.

\subsection{Teknik Pengumpulan Data}

Dalam hal ini prosedur pengumpulan data dilakukan dengan cara yaitu :

1. Wawancara

Adalah metode pengumpulan data dengan cara bertanya secara langsung kepada responden yaitu pengguna produk Telkomsel.

2. Menggunakan cara menyebarkan kuesioner kepada responden dengan daftar pertanyaan yang ada, dan ditujukan kepada tiap orang yang memenuhi syarat.

3. Studi kepustakaan yaitu mengumpulkan data dari buku-buku, internet dan literatur yang 
berhubungan dengan masalah yang diteliti.

\subsection{Teknik Analisis Data}

\subsubsection{Uji Validitas dan Uji Realibilitas}

Data dalam penelitian ini menggunakan data primer yang berasal dari kuesioner, untuk itu sebelum melakukan pengujian diperlukan pengujian validitas dan reliabilitas terhadap indikator atau pertanyaan-pertanyaan kuesioner.

Uji validitas digunakan untuk mengukur sah atau tidak suatu kuesioner. Suatu kuesioner dikatakan valid jika pertanyaan atau pernyataan pada kuesioner mampu mengungkapkan sesuatu yang akan diukur oleh kuesioner tersebut. Ghozali ( 2013:53).

Uji reabilitas merupakan alat untuk mengukur suatu kuesioner yang merupakan Indikator dari variabel atau konstruk. Suatu kuesioner dikatakan reliabel atau handal jika jawaban seseorang terhadap pernyataan adalah konsisten atau stabil dari waktu ke waktu (Ghozali, 2013:47).

\subsubsection{Uji Hipotesis dengan Analisis Diskriminan}

Analisis data dapat dilakukan dengan komputer, dengan Software SPSS terhadap output sebagai berikut :

1. Analysis Cases Processing Summary Untuk mengetahui valid atau tidaknya kasus-kasus yang diteliti.

2. Group Statistics Untuk membandingkan variabel bebas dari masing-masing grup.

3. Test Of Equality of Group Means Untuk menguji apakah ada perbedaan yang signifikan antara kelompok. Dengan berpedoman pada :

a. Angka Wilk"s Lambda berkisar 0 sampai 1, semakin mendekati 0 maka data tiap kelompok semakin berbeda, sedang semakin mendekati 1 maka data tiap kelompok cenderung sama.

b. F test, dengan batas signifikan 0,1
- Jika Sig. > 0,1 berarti tidak ada perbedaan antar kelompok.

- Jika Sig. < 0,1 berarti ada perbedaan antar kelompok.

4. Variables Entered/Removed

a. Untuk mengetahui variabel-variabel yang dianalisis, variabel mana yang dapat dimasukkan (entered) dalam persamaan diskriminan.

b. Dengan F Hitung pada statistik, untuk mengetahui urutan pertahapan, dimulai dari yang memiliki angka tertinggi. Bagi variabel yang perolehan angka $\mathrm{F}$ nya tidak signifikan, tidak entered, berarti removed (dibuang).

5. Eigenvalues

Untuk mengetahui persentase variabel terikat yang dapat dijelaskan oleh variabel bebas yang terpilih dalam model diskriminan. Persentase diketahui dengan mengkuadratkan angka Canonical Correlation.

6. Wilk"s Lambda

Untuk mengetahui ada atau tidaknya perbedaan yang signifikan antara masing-masing grup, yaitu dengan melihat angka besaran Chi Square.

7. Struktur Matrix

Untuk mengetahui urutan variabel bebas (kualitas produk, harga, promosi, dan citra produk) yang membedakan. Dari yang paling besar membedakan dengan angka postitif sampai dengan yang terkecil membedakan dengan angka negatif.

8. Standardized Canonical Discriminant Function Coefficients

Untuk menunjukan koefisien pada setiap variabel yang berperan dalam melakukan diskriminasi.

9. Classification Result

Untuk menentukan apakah model diskriminan tersebut mampu melakukan klasifikasi/prediksi responden dengan tepat untuk analisis diskriminan. 


\section{HASIL DAN PEMBAHASAN}

\subsection{Hasil Penelitian}

Pilihan kepuasan konsumen (uji

perbedaan rata-rata)

\section{Tabel 2. Uji Beda Rata-rata Kualitas}

Produk

\begin{tabular}{|c|l|c|c|}
\hline No & \multicolumn{1}{|c|}{ Kualitas Produk } & \multicolumn{2}{|c|}{ Nilai Kepuasan } \\
\cline { 3 - 4 } & $\begin{array}{c}\text { Operator Seluler } \\
\text { Lainnya }\end{array}$ & $\begin{array}{c}\text { Operator } \\
\text { Seluler } \\
\text { Telkomsel }\end{array}$ \\
\hline 1 & $\begin{array}{l}\text { Product Variety (Pilihan produk } \\
\text { yang beraneka ragam sesuai dengan } \\
\text { kebutuhan) }\end{array}$ & 382 & 418 \\
\hline 2 & $\begin{array}{l}\text { Feature (Fitur layanan yang lebih } \\
\text { menarik dari operator seluler lain) }\end{array}$ & 361 & 406 \\
\hline 3 & $\begin{array}{l}\text { Performance Quality (Memiliki } \\
\text { sinyal jaringan yang kuat di seluruh } \\
\text { wilayah) }\end{array}$ & 317 & 459 \\
\hline 4 & $\begin{array}{l}\text { Services (Pelayanan customer } \\
\text { service dapat memberikan informasi } \\
\text { yang di butuhkan pelanggan dan } \\
\text { memberikan solusi) }\end{array}$ & 376 & 409 \\
\hline 5 & $\begin{array}{l}\text { Reability (Jangkauan jaringan } \\
\text { produk yang luas) }\end{array}$ & 345 & 449 \\
\hline 6 & \begin{tabular}{l} 
Returns (Feed back yang menarik) \\
\hline Rata-rata
\end{tabular} & 346 & 388 \\
\hline
\end{tabular}

Sumber: Data yang dioleh oleh penulis, 2018

Berdasarkan hasil perbedaan rata-rata kualitas produk, menunjukkan nilai kepuasan konsumen terhadap operator seluler Telkomsel 421.5 point yang artinya tingkat kepuasan konsumen operator seluler merasa sangat puas terhadap kualitas produk operator seluler Telkomsel, sedangkan nilai kepuasan konsumen terhadap operator seluler lainnya 354,5 point yang artinya tingkat kepuasan konsumen operator seluler merasa puas terhadap kualitas produk operator seluler lainnya. Selisih keduanya 67 point dan Telkomsel lebih besar nilainya sehingga Telkomsel memiliki tingkat kepuasan kualitas produk lebih baik dibandingkan operator seluler lainnya.

Tabel 3. Uji Beda Rata-rata Harga

\begin{tabular}{|c|c|c|c|}
\hline \multirow{2}{*}{ No } & \multicolumn{1}{|c|}{ Harga } & \multicolumn{2}{|c|}{ Nilai Kepuasan } \\
\cline { 3 - 4 } 2 & $\begin{array}{c}\text { Operator } \\
\text { Seluler } \\
\text { Lainnya }\end{array}$ & $\begin{array}{c}\text { Operator } \\
\text { Seluler } \\
\text { Telkomsel }\end{array}$ \\
\hline 1 & $\begin{array}{l}\text { Keterjangkauan Harga (Harga } \\
\text { tarif layanan yang terjangkau) }\end{array}$ & 385 & 327 \\
\hline 2 & $\begin{array}{l}\text { Kesesuaian harga dengan } \\
\text { kualitas produk (Kualitas } \\
\text { pelayanan produk sesuai dengan } \\
\text { harga tarif yang diberikan) }\end{array}$ & 357 & 410 \\
\hline 3 & $\begin{array}{l}\text { Daya saing harga (Harga tarif } \\
\text { layanan yang kompetitif dengan } \\
\text { operator seluler lain) }\end{array}$ & 362 & 356 \\
\hline \multicolumn{2}{|c|}{ Rata-rata } & 368 & 364,33 \\
\hline
\end{tabular}

Sumber: Data yang dioleh oleh penulis, 2018

Berdasarkan hasil perbedaan rata-rata harga, menunjukkan nilai kepuasan konsumen terhadap operator seluler Telkomsel 364.33 poin yang artinya tingkat kepuasan konsumen operator seluler merasa puas terhadap harga operator seluler Telkomsel. Sedangkan nilai kepuasan konsumen terhadap operator seluler lainnya 368 point yang artinya tingkat kepuasan konsumen operator seluler merasa puas terhadap harga operator seluler lainnya. Selisih keduanya 3.67 point dan Telkomsel lebih kecil nilainya sehingga operator seluler lainnya memiliki tingkat kepuasan harga lebih baik dibandingkan operator seluler Telkomsel.

Tabel 4. Uji Beda Rata-rata Promosi

\begin{tabular}{|c|c|c|c|}
\hline \multirow[b]{2}{*}{ No } & \multirow[b]{2}{*}{ Promosi } & \multicolumn{2}{|c|}{ Nilai Kepuasan } \\
\hline & & $\begin{array}{l}\text { Operator } \\
\text { Seluler } \\
\text { Lainnya }\end{array}$ & $\begin{array}{l}\text { Operator } \\
\text { Seluler } \\
\text { Telkomsel }\end{array}$ \\
\hline 1 & $\begin{array}{l}\text { Advertiding (Iklan produk yang } \\
\text { memberikan penawaran menarik melalui } \\
\text { berbagai media) }\end{array}$ & 377 & 413 \\
\hline 2 & 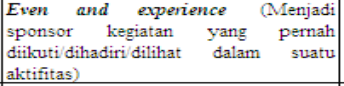 & 340 & 387 \\
\hline 3 & $\begin{array}{l}\text { Online and social media marketing } \\
\text { (Penawaran produk yang dapat } \\
\text { ditemukan melalui media sosial dan } \\
\text { online) }\end{array}$ & 376 & 410 \\
\hline 4 & $\begin{array}{l}\text { Word of mouth (Penawaran produkt } \\
\text { yang menarik dari cerita pengalaman } \\
\text { pengguna operator seluler) }\end{array}$ & 350 & 395 \\
\hline 5 & $\begin{array}{l}\text { Direct and database marketing } \\
\text { (Adanya penawaran menarik produk } \\
\text { melatui SMS, Telpon atau Email terkait } \\
\text { produk) }\end{array}$ & 358 & 388 \\
\hline 6 & $\begin{array}{l}\text { Personal selling (A.jakan penggunaan } \\
\text { oleh sales atau orang terdekat dengan } \\
\text { adanya penawaran produk yang } \\
\text { menarik) }\end{array}$ & 342 & 373 \\
\hline & Rata-rata & 357,17 & 394,33 \\
\hline
\end{tabular}

Sumber: Data yang dioleh oleh penulis, 2018 
Berdasarkan hasil perbedaan rata-rata promosi, menunjukkan nilai kepuasan konsumen terhadap operator seluler Telkomsel 394,33 point yang artinya tingkat kepuasan konsumen operator seluler merasa puas terhadap promosi operator seluler Telkomsel, sedangkan nilai kepuasan konsumen terhadap operator seluler lainnya 357,17 point yang artinya tingkat kepuasan konsumen operator seluler merasa puas terhadap promosi operator seluler lainnya. Selisih keduanya 37,16 point dan Telkomsel lebih besar nilainya sehingga Telkomsel memiliki tingkat kepuasan promosi lebih baik dibandingkan operator seluler lainnya.

Tabel 5. Uji Beda Rata-rata Brand Image

\begin{tabular}{|c|c|c|c|}
\hline \multirow{2}{*}{ No } & \multicolumn{1}{|c|}{ Brand Image } & \multicolumn{2}{|c|}{ Nilai Kepuasan } \\
\cline { 2 - 4 } & $\begin{array}{c}\text { Operator } \\
\text { Seluler } \\
\text { Lainnya }\end{array}$ & $\begin{array}{c}\text { Operator } \\
\text { Seluler } \\
\text { Telkomsel }\end{array}$ \\
\hline 1 & $\begin{array}{l}\text { Citra korporat (Memiliki produk yang } \\
\text { terpercaya dan dikenal masyarakat) }\end{array}$ & 379 & 448 \\
\hline 2 & $\begin{array}{l}\text { Citra korporat Memiliki perhatian } \\
\text { yang baik untuk menangani keluhan } \\
\text { setiap pelanggan) }\end{array}$ & 350 & 400 \\
\hline 3 & $\begin{array}{l}\text { Citra korporat (Menyediakan berbagai } \\
\text { media untuk melayani pelanggan dan } \\
\text { calon pelanggan) }\end{array}$ & 352 & 399 \\
\hline 4 & $\begin{array}{l}\text { Citra korporat (Operator seluler yang } \\
\text { mampu menjaring pelanggan terbesar di } \\
\text { Indonesia) }\end{array}$ & 333 & 438 \\
\hline 5 & $\begin{array}{l}\text { Citra Produk (Jaringan yang luas dan } \\
\text { kuat diseluruh wilayah) }\end{array}$ & 316 & 452 \\
\hline 6 & $\begin{array}{l}\text { Citra Produk (Memiliki kecepatan } \\
\text { data internet yang tinggi) }\end{array}$ & 324 & 432 \\
\hline 7 & $\begin{array}{l}\text { Citra Produk (Memiliki penawaran } \\
\text { harga yang menarik untuk semua } \\
\text { produk) }\end{array}$ & 369 & 358 \\
\hline 8 & $\begin{array}{l}\text { Citra Produk (Produk dapat diperoleh } \\
\text { dengan mudah oleh semua lapisan } \\
\text { masyarakat) }\end{array}$ & 374 & 402 \\
\hline 9 & $\begin{array}{l}\text { Citra Produk (Semua produk memiliki } \\
\text { tawaran bonus yang menarik) }\end{array}$ & 369 & 371 \\
\hline & $\begin{array}{l}\text { Citra Pemakai (Semua lapisan } \\
\text { masyarakat lebih banyak memakai } \\
\text { produk (kesamaan produk yang } \\
\text { dipakai)) }\end{array}$ & 352 & 381 \\
\hline & \multicolumn{1}{|c|}{ Rata-rata } & 351,8 & 408,1 \\
\hline
\end{tabular}

Sumber: Data yang dioleh oleh penulis, 2018

Berdasarkan hasil perbedaan rata-rata promosi, menunjukkan nilai kepuasan konsumen terhadap operator seluler Telkomsel 408,10 point yang artinya tingkat kepuasan konsumen operator seluler merasa sangat puas terhadap brand image operator seluler Telkomsel, sedangkan nilai kepuasan konsumen terhadap operator seluler lainnya 351,80 point yang artinya tingkat kepuasan konsumen operator seluler merasa puas terhadap brand image operator seluler lainnya. Selisih keduanya 56,3 point dan Telkomsel lebih besar nilainya sehingga Telkomsel memiliki tingkat kepuasan brand image lebih baik dibandingkan operator seluler lainnya.

Tabel 6. Uji Beda Rata-rata Variabel

\begin{tabular}{|c|c|c|c|}
\hline \multirow[b]{2}{*}{ No. } & \multirow[b]{2}{*}{ Variabel } & \multicolumn{2}{|c|}{ Rata-rata Nilai Kepuasan } \\
\hline & & $\begin{array}{c}\text { Operator } \\
\text { Seluler } \\
\text { Lainnya }\end{array}$ & $\begin{array}{l}\text { Operator } \\
\text { Seluler } \\
\text { Telkomsel }\end{array}$ \\
\hline 1 & $\begin{array}{l}\text { Kualitas } \\
\text { Produk }\end{array}$ & 354,5 & 421,5 \\
\hline 2 & Harga & 368 & 364,33 \\
\hline 3 & Promosi & 357,17 & 394,33 \\
\hline 4 & Brand Image & 351,8 & 408,1 \\
\hline \multicolumn{2}{|c|}{ Total Rata-rata } & 357,87 & 397,07 \\
\hline
\end{tabular}

Sumber: Data yang dioleh oleh penulis, 2018

Berdasarkan hasil perbedaan total ratarata variabel, menunjukkan nilai kepuasan konsumen terhadap operator seluler Telkomsel 397,07 point yang artinya tingkat kepuasan konsumen operator seluler merasa puas terhadap operator seluler Telkomsel, sedangkan nilai kepuasan konsumen terhadap operator seluler lainnya 357,87 point yang artinya tingkat kepuasan konsumen operator seluler merasa puas terhadap operator seluler lainnya. Selisih keduanya 39,2 point dan Telkomsel lebih besar nilainya sehingga Telkomsel memiliki tingkat kepuasan lebih baik dibandingkan operator seluler lainnya.

\subsubsection{Analisis Diskriminan}

Tabel 7. Analysis Case Processing Summary 


\begin{tabular}{|c|c|c|c|}
\hline \multicolumn{2}{|c|}{ Unweighted Cases } & $\mathrm{N}$ & Percent \\
\hline \multicolumn{2}{|l|}{ Valid } & 200 & 100.0 \\
\hline Excluded & $\begin{array}{l}\text { Missing or out-of- } \\
\text { range group codes }\end{array}$ & 0 & .0 \\
\hline & $\begin{array}{l}\text { At least one missing } \\
\text { discriminating variable }\end{array}$ & 0 & .0 \\
\hline & $\begin{array}{l}\text { Both missing or out-of- } \\
\text { range group codes and } \\
\text { at least one missing } \\
\text { discriminating variable }\end{array}$ & 0 & .0 \\
\hline & Total & 0 & .0 \\
\hline \multicolumn{2}{|l|}{ Total } & 200 & 100.0 \\
\hline
\end{tabular}

Sumber: Data yang diolah oleh penulis dengan SPSS, 2018.

Tabel di atas menunjukan tidak ada data yang hilang karena jumlah total $\mathrm{N}$ tidak ada yang kurang dengan jumlah data valid.

Tabel 8. Group Statistics

\begin{tabular}{|c|c|c|c|c|c|}
\hline \multirow{2}{*}{ Simcard } & & \multirow{2}{*}{ Mean } & \multirow{2}{*}{$\begin{array}{c}\text { Std. } \\
\text { Deviation }\end{array}$} & \multicolumn{2}{|c|}{ Valio $N$ (listwiss) } \\
\hline & & & & Unweighted & Weighted \\
\hline \multirow{4}{*}{ Lainnya } & $\begin{array}{l}\text { Kualitas_Prod } \\
\text { uvk }\end{array}$ & 21.78 & 2.813 & 100 & 100.000 \\
\hline & Harga & 11.28 & 1.609 & 100 & 100.000 \\
\hline & Promosi & 21.92 & 2.553 & 100 & 100.000 \\
\hline & Brand_Image & 35.69 & 4.528 & 100 & 100.000 \\
\hline \multirow{4}{*}{ Telkomsel } & \begin{tabular}{|l|} 
Kualitas__Prod \\
uks
\end{tabular} & 25.70 & 2.410 & 100 & 100.000 \\
\hline & Harga & 11.08 & 1.879 & 100 & 100.000 \\
\hline & Promosi & 24.06 & 2.566 & 100 & 100.000 \\
\hline & Brand_Image & 41.33 & 4.367 & 100 & 100.000 \\
\hline \multirow{4}{*}{ Total } & $\begin{array}{l}\text { Kualitas_Prod } \\
\text { ut: }\end{array}$ & 23.74 & 3.269 & 200 & 200.000 \\
\hline & Harga & 11.18 & 1.747 & 200 & 200.000 \\
\hline & Promosi & 22.99 & 2.769 & 200 & 200.000 \\
\hline & Brand_Image & 38.51 & 5.261 & 200 & 200.000 \\
\hline
\end{tabular}

Sumber: Data yang diolah oleh penulis dengan SPSS, 2018.

Kualitas produk, promosi, dan brand image memiliki nilai yang baik dari operator seluler lainnya namun harga operator seluler lainnya memiliki penilaian yang baik dibandingkan dengan pengguna operator seluler Telkomsel.

Tabel 9. Tests of Equality of Group Means

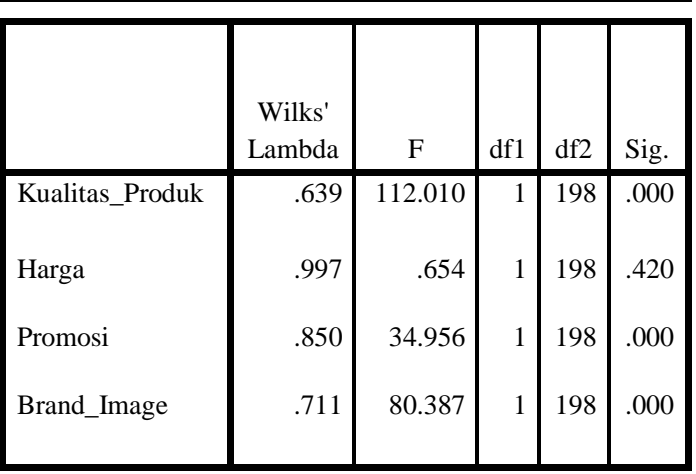

Sumber: Data yang diolah oleh penulis dengan SPSS, 2018.

\section{Significancy:}

a. Sig. > 0.1 tidak ada perbedaan antar grup

b. Sig. $<0.1$ ada perbedaan antar grup

Pada variabel Kualitas Produk, Promosi, Brand Image menunjukan Sig. < 0,1 . Dengan angka: 0,000 . Yang artinya 3 variabel tersebut menunjukan ada perbedaan antar grup. Sehingga dapat di interpretasikan: Kualitas Produk, Promosi, dan Brand Image yang baik menjadi alasan pengguna operator seluler melakukan perpindahan ke merek Telkomsel. Atau Kualitas Produk, Promosi, dan Brand Image yang tidak baik membuat pengguna operator seluler melakukan perpindahan merek ke operator seluler Telkomsel dari merek operator seluler lainnya.

Tabel 10. Variables Entered/Removed ${ }^{a, b, c, d}$

\begin{tabular}{|c|c|c|c|c|c|c|c|}
\hline \multirow[b]{3}{*}{ Step } & \multirow[b]{3}{*}{ Entered } & \multicolumn{6}{|c|}{ Min. D Squared } \\
\hline & & \multirow[t]{2}{*}{ Statistic } & \multirow{2}{*}{$\begin{array}{c}\text { Between } \\
\text { Groups }\end{array}$} & \multicolumn{4}{|c|}{ Exact $F$} \\
\hline & & & & Statistic & df1 & df 2 & Sig. \\
\hline 1 & $\begin{array}{l}\text { Kualitas_ } \\
\text { Produl: }\end{array}$ & 2.240 & $\begin{array}{l}\text { Lainnya } \\
\text { and } \\
\text { Tellkomsel }\end{array}$ & 112.010 & 1 & 198.000 & 4,94E-18 \\
\hline 2 & $\begin{array}{l}\text { Brand_ } \\
\text { Image }\end{array}$ & 3.774 & $\begin{array}{l}\text { Lainnya } \\
\text { and } \\
\text { Tellkomsel }\end{array}$ & 93.864 & 2 & 197.000 & $2,33 E-26$ \\
\hline 3 & Promosi & 4.373 & $\begin{array}{l}\text { Lainnya } \\
\text { and } \\
\text { Tellkomsel }\end{array}$ & 72.150 & 3 & 196.000 & $1,76 \mathrm{E}-28$ \\
\hline
\end{tabular}

Sumber: Data yang diolah oleh penulis dengan SPSS, 2018.

Dari data tersebut kita dapat mengetahui pengguna operator seluler Telkomsel dan operaor seluler lainnya 
memiliki perilaku yang berbeda, karena Sig. < 0,1 dengan angka nol koma di atas 20 kali, yang artinya perpindahan merek ke operator seluler Telkomsel dari operator seluler lainnya dipengaruhi kualitas produk, brand image dan promosi.

Tabel 11. Eigenvalues

\begin{tabular}{|l|c|c|c|c|}
\hline $\begin{array}{l}\text { Functi } \\
\text { on }\end{array}$ & $\begin{array}{c}\text { Eigenval } \\
\text { ue }\end{array}$ & $\begin{array}{c}\text { \% of } \\
\text { Varian } \\
\text { ce }\end{array}$ & $\begin{array}{c}\text { Cumulati } \\
\text { ve } \%\end{array}$ & $\begin{array}{c}\text { Canonica } \\
1 \\
\text { Correlati } \\
\text { on }\end{array}$ \\
\hline 1 & $1.104^{\mathrm{a}}$ & 100.0 & 100.0 & .724 \\
\hline
\end{tabular}

a. First 1 canonical discriminant functions were used in the analysis.

Sumber: Data yang diolah oleh penulis dengan SPSS, 2018.

Lihat Canonical Correlation : 0,724 dikuadratkan menjadi $0,5242=52,42 \%$ Variance dari variabel Y (Brand Switching) dapat dijelaskan oleh model diskriminan yang terbentuk oleh 3 variabel bebas (Kualitas Produk, Promosi, Citra Merek).

Tabel 12. Wilks' Lambda

\begin{tabular}{|l|r|r|r|r|}
\hline & & & & \\
$\begin{array}{l}\text { Test of } \\
\text { Function(s) }\end{array}$ & $\begin{array}{c}\text { Wilks' } \\
\text { Lambda }\end{array}$ & \multicolumn{1}{c|}{$\begin{array}{c}\text { Chi- } \\
\text { square }\end{array}$} & Df & Sig. \\
\hline 1 & .475 & 146.196 & 3 & .000 \\
\hline
\end{tabular}

Sumber: Data yang diolah oleh penulis dengan SPSS, 2018.

Pada model diskriminan wilks' Lambda, Sig. < 0,1 dengan angka Sig. : 0,000 . Yang artinya terdapat perbedaan yang signifikan antara kedua grup (operator seluler Telkomsel dan operator seluler lainnya) pada model diskriminan.

Tabel 13. Structure Matrix

\begin{tabular}{|l|r|}
\hline & \multicolumn{2}{|c|}{ Function } \\
\cline { 2 - 3 } & 1 \\
\hline Kualitas_Produk & .716 \\
Brand_Image & .606 \\
Promosi & .400 \\
Harga $^{a}$ & -.056 \\
\hline
\end{tabular}

Sumber: Data yang diolah oleh penulis dengan SPSS, 2018

Pada tabel Function at Group Centroids dapat kita lihat Operator Seluler lainnya memiliki tanda angka (-) dan Telkomsel memilki tanda angka (+). Dapat disimpulkan bahwa variabel bebas yang termasuk pada Telkomsel adalah Kualitas Produk, Promosi, Brand Image karena memiliki tanda positif. Variabel bebas yang termasuk pada Grup operator seluler lainnya adalah harga karena memiliki tanda negatif. Hal ini menunjukan bahwa pelanggan Telkomsel lebih tertarik pada kualitas produk, promosi, dan brand image. Sedangkan pelanggan operator seluler lainnya lebih tertarik pada harga yang murah.

Tabel 14. Standardized Canonical Discriminant Function Coefficients

\begin{tabular}{|l|r|}
\hline & \multicolumn{2}{|c|}{ Function } \\
\cline { 2 - 2 } & \multicolumn{2}{|c|}{1} \\
\hline Kualitas_Produk & .708 \\
Promosi & .371 \\
Brand_Image & .569 \\
\hline
\end{tabular}

Sumber: Data yang diolah oleh penulis dengan SPSS, 2018

Jadi $Z_{1}=0,708 x_{1}+0,371 x_{2}+0,569 x_{3}$ dapat disimpulkan dari model Telkomsel bahwa: Jika kualitas produk meningkat satu satuan maka perbedaan Telkomsel akan meningkat sebesar 0,708. Jika promosi meningkat satu satuan maka perbedaan Telkomsel akan meningkat sebesar 0,371. Jika brand image meningkat satu satuan maka perbedaan Telkomsel akan meningkat sebesar 0,569. 
Tabel 15. Classification Results ${ }^{b, c}$

\begin{tabular}{|c|c|c|c|c|c|}
\hline & & Simcard & $\begin{array}{l}\text { Predict } \\
\text { Mem }\end{array}$ & $\begin{array}{l}\text { d Group } \\
\text { ership }\end{array}$ & Total \\
\hline & & & Lainnya & Telkomsel & \\
\hline Original & Count & Lainnya & 89 & 11 & 100 \\
\hline & & Telkomsel & 13 & 87 & 100 \\
\hline & $\%$ & Lainnya & 89.0 & 11.0 & 100.0 \\
\hline & & Telkomsel & 13.0 & 87.0 & 100.0 \\
\hline Cross- & Count & Lainnya & 89 & 11 & 100 \\
\hline validated & & Telkomsel & 14 & 86 & 100 \\
\hline & $\%$ & Lainnya & 89.0 & 11.0 & 100.0 \\
\hline & & Telkomsel & 14.0 & 86.0 & 100.0 \\
\hline
\end{tabular}

Sumber: Data yang diolah oleh penulis dengan SPSS, 2018

Lihat data original operator seluler di tabel pada Count:

$$
\begin{array}{ll}
\text { Lainnya-lainnya } & =89.0 \\
\text { Telkomsel-telkomsel } & =87.0 \\
\text { Total Responden } & =200(100+100)
\end{array}
$$

1. Sehigga ketepatan model untuk analisis diskriminan:

$$
\text { (89 87) } / 200=88 \%
$$

\section{KESIMPULAN DAN SARAN}

\subsection{Kesimpulan}

Kesimpulan yang diperoleh dari penelitian ini yaitu :

1. Variabel yang digunakan dalam penelitian ini secara keseluruhan valid dan reliabel sehingga data yang diperoleh dapat digunakan dalam Analisis diskriminan operator seluler Telkomsel dan operator seluler lainnya.

2. Nilai kepuasan konsumen operator seluler secara rata-rata lebih puas kepada operator seluler Telkomsel, yang ditunjukan oleh nilai rata-rata kepuasan sebesar 397,07 point sedangkan operator seluler lainnya sebesar 357,87 point.

3. Ada 3 perbedaan persepsi konsumen operator seluler terhadap Telkomsel. Perbedaan persepsi tersebut ada pada variabel kualitas produk, promosi dan brand image. Artinya pengguna operator seluler akan membandingkan 3 variabel tersebut sebelum melakukan perpindahan ke merek Telkomsel

\subsection{Saran}

Rekomendasi yang dapat diberikan dari penelitian ini yaitu :

1. Konsumen operator seluler lebih puas dengan operator seluler Telkomsel berdasarkan uji rata-rata persepsi dan pilihan konsumen. Sehingga perusahaan operator seluler diharapkan dapat memberikan kepuasan kepada konseumennya seperti yang telah Telkomsel berikan.

2. Faktor yang menentukan keputusan brand switching ke operator seluler Telkomsel adalah kualitas produk, promosi dan brand image. Perusahaan operator seluler sebaiknya memperhatikan ketiga hal ini agar dapat selalu mempertahankan bahkan meningkatkan jumlah penggunanya

\section{DAFTAR PUSTAKA}

Abisatya, Diaz. 2009. Competitive Advertising serta Dampaknya pada Perilaku Brand Switching Konsumen. Jurnal Bisnis \& Manajemen Universitas Padjajaran, Bandung.

Alma, Buchari.(2014). Manajemen Pemasaran dan Pemasaran Jasa. Alfabeta, Bandung.

--------. 2013. Manajemen Pemasaran dan Pemasaran Jasa. Alfabeta, Bandung.

-------. 2012. Manajemen Pemasaran Dan

Pemasaran Jasa. Alfabeta, Bandung.

-------. 2011. Manajemen Pemasaran dan Pemasaran Jasa. Alfabeta, Bandung.

Assauri, Sofyan. 2011. Manajemen

Pemasaran Dasar, Konsep, dan strategi. PT. Grafindopersada, Jakarta.

Bastian, Danny Alexander.(2014). Analisa

Pengaruh Citra Merek (Brand

Image) Dan Kepercayaan Merek (Brand Trust) Terhadap Loyalitas Merek (Brand Loyalty) . ADES (PT. Ades 
Alpindo Putra Setia). Jurnal Manajemen Pemasaran Universitas Kristen Petra, Surabaya.

Bilson, Simamora. 2011. Memenangkan Pasar dengan Pemasaran Efektif dan Profitabel. PT. Gramedia Pustaka Utama, Jakarta.

Daryanto. 2011. Sari Kuliah Manajemen Pemasaran. PT Sarana Tutorial Nurani Sejahtera, Bandung.

Hawkins, Del I., dan David L. Mothersbaugh. 2010. Consumer Behavior: Building Marketing Strategy, Elevent Edition. McGrawHill, New York.

Ghouri, Arsalan Mujahid., Siddqui Usman Ali, Asif Shaikh, et all. 2010. Determinants Analysis of Customer Switching Behavior in Private Banking Sector of Pakistan Vol 2, No 7. Institute of business and technology, Karachi.

Ghozali, Imam. 2013. Aplikasi Analisis Multivariat dengan Program IBM SPSS 21, Edisi 7. Universitas Diponegoro, Semarang.

Gitosudarmo, Indriyo. 2012. Manajemen Pemasaran. BPFE, Yogyakarta

J. Setiadi, Nugroho. 2008. Perilaku Konsumen. PT Kencana, Jakarta.

Johnson, R.A. dan D.W. Wichern. 1982. Applied Multivariate Statistical Analysis. Griffin, London.

Kasmir. 2011. Analisis Laporan Keuangan. PT Raja Grafindo Persada, Jakarta.

Katadata news and research. 2018. https://databoks.katadata.co.id/datapub lish/2017/05/03/siapa-operator-seluleryang-mempunyai-pelangganterbanyak, Rabu, 3 Mei 2017.

Keller, Kevin Lane. (2013). Strategic Brand Management: Building, Measuring, and Managing Brand Equity, Global Edition. Pearson Prentice Hall, Inc, New Jersey.

Sulistyari, Ikanita Novirina. 2012. Analisis Pengaruh Citra Merek, Kualitas
Produk, Dan Harga Terhadap Minat Beli Produk Oriflamme (Studi Kasus Mahasiswi Fakultas Ekonomika Dan Bisnis Jurusan Manajemen Universitas Diponegoro Semarang). Jurnal Manajemen, Volume 1 No. 1 Universitas Diponegoro, Semarang.

Sunyoto, Danang. 2014. Konsep Dasar

Riset Pemasaran \& Perilaku Konsumen. CAPS, Yogyakarta.

Suseno, Adi. Analisis Brand Switching Produk Telkomsel dan Implikasinya Pada Bauran Produk Untuk Segmen RemajaSiswa SLTA di Bogor. Skripsi Departmen Manajemen IPB, Bogor.

Tjiptono, Fandy. 2014. Pemasaran Jasa. Andi, Yogyakarta.

Undang-undang Republik Indonesia Nomor 36 tahun 1999 tentang Telekomunikasi

Yunita, Irma. 2013. Analisis komparasi atribut produk sepeda motor matik Honda Beat dan Yamaha Mio J F1. (Study kasus pada pengguna sepeda motor merek Honda Beat F1 Dan Yamaha Mio J F1 di Daerah Rungkut Madya Kecamatan Gunung Anyar). Universitas Pembangunan Nasional Veteran, Surabaya. 